\title{
In vivo magnetic resonance imaging tracking of C6 glioma cells labeled with superparamagnetic iron oxide nanoparticles
}

\author{
Monitoramento in vivo por imagem por ressonância magnética de células C6 \\ de glioma marcadas com nanopartículas superparamagnéticas de óxido de ferro
}

\author{
Javier Bustamante Mamani ${ }^{1}$, Jackeline Moraes Malheiros ${ }^{2}$, Ellison Fernando Cardoso ${ }^{3}$, Alberto Tannús ${ }^{2}$, \\ Paulo Henrique Silveira ${ }^{1}$, Lionel Fernel Gamarra ${ }^{1}$
}

\begin{abstract}
Objective: The aim of the current study was to monitor the migration of superparamagnetic iron oxide nanoparticle (SPION)-labeled C6 cells, which were used to induce glioblastoma tumor growth in an animal model, over time using magnetic resonance imaging (MRI), with the goal of aiding in tumor prognosis and therapy. Methods: Two groups of male Wistar rats were used for the tumor induction model. In the first group $(n=3)$, the tumors were induced via the injection of SPION-labeled C6 cells. In the second group $(n=3)$, the tumors were induced via the injection of unlabeled $\mathrm{C} 6$ cells. Prussian Blue staining was performed to analyze the SPION distribution within the $\mathrm{C} 6$ cells in vitro. Tumor-inducing $\mathrm{C} 6$ cells were injected into the right frontal cortex, and subsequent tumor monitoring and SPION detection were performed using $\mathrm{T}_{2}{ }^{-}$and $\mathrm{T}_{2}{ }^{*}$-weighted MRI at a $2 \mathrm{~T}$ field strength. In addition, cancerous tissue was histologically analyzed after performing the MRI studies. Results: The in vitro qualitative evaluation demonstrated adequate distribution and satisfactory cell labeling of the SPIONs. At 14 or 21 days after C6 injection, a SPIONinduced $\mathrm{T}_{2}$ - and $\mathrm{T}_{2}{ }^{*}$-weighted MRI signal reduction was observed within the lesion located in the left frontal lobe on parasagittal topography. Moreover, histological staining of the tumor tissue with Prussian Blue revealed a broad distribution of SPIONs within the C6 cells. Conclusion: MRI analyses exhibit potential for monitoring the tumor growth of $\mathrm{C} 6$ cells efficiently labeled with SPIONs.
\end{abstract}

Keywords: Glioma; Nanoparticles; Magnetic resonance imaging; Animal models

\section{RESUMO}

Objetivo: Realizar monitoramento temporal por imagem por ressonância magnética da migração de células C6 marcadas com nanopartículas superparamagnéticas de óxido de ferro utilizadas na indução de tumor de glioblastoma no modelo animal, com o intuito de auxiliar no prognóstico e na terapêutica de tumores. Métodos: Para 0 modelo animal de indução de tumor, foram utilizados ratos Wistar machos, divididos em dois grupos. No primeiro grupo $(n=3), 0$ tumor foi induzido por células C6 marcadas com nanopartículas superparamagnéticas de óxido de ferro e, no segundo grupo, $(n=3) 0$ tumor foi induzido por C6 não marcadas. Foi realizada análise in vitro da distribuição intracelular das nanopartículas superparamagnéticas de óxido de ferro nas células C6 mediante coloração de azul da prússia. As células C6 para a indução de tumor foram implantadas no córtex frontal direito. Posteriormente, foram realizados o monitoramento tumoral e a detecção das nanopartículas superparamagnéticas de óxido de ferro por sequências de imagem por ressonância magnética ponderadas em $\mathrm{T}_{2}$ e $\mathrm{T}_{2}{ }^{*}$, em campo de $2 \mathrm{~T}$. Após os estudos de imagem por ressonância magnética, 0 tecido tumoral foi submetido à análise histológica. Resultados: A avaliação qualitativa do estudo in vitro mostrou boa distribuição e satisfatória marcação celular com nanopartículas superparamagnéticas de óxido de ferro. No monitoramento realizado por imagem por ressonância magnética, foi observada, no $14^{\circ}$ e $21^{\circ}$ dia, redução do sinal em $\mathrm{T}_{2}$ e $\mathrm{T}_{2}{ }^{*}$, induzida pelas nanopartículas superparamagnéticas de óxido de ferro, na lesão localizada no lobo frontal esquerdo em topografia parassagital. Por meio da marcação com azul da prússia, a análise histológica

\footnotetext{
Study carried out at the Instituto Israelita de Ensino e Pesquisa Albert Einstein, Hospital Israelita Albert Einstein - HIAE, São Paulo (SP), Brazil; in collaboration with the in vivo Magnetic Resonance Imaging and Spectroscopy Center at the Instituto de Física de São Carlos da Universidade de São Paulo - USP, São Carlos (SP), Brazil.

1 Instituto do Cérebro - InCE, Hospital Israelita Albert Einstein - HIAE, São Paulo (SP), Brazil.

${ }^{2}$ Centro de Imagens e Espectroscopia in vivo por Ressonância Magnética, Instituto de Física de São Carlos, Universidade de São Paulo - USP, São Carlos (SP), Brazil.

${ }^{3}$ Department of Diagnostic Imaging and Instituto do Cérebro - InCe, Hospital Israelita Albert Einstein - HIAE, São Paulo (SP), Brazil.

Corresponding author: Javier Bustamante Mamani - Avenida Albert Einstein, 627/701 - Morumbi - Zip code: 05651-901 - São Paulo (SP), Brazil - Phone: (55 11) 2151-2044 - E-mail: javierbm@einstein.br Received on: Apr 5, 2012 - Accepted on: May 23, 2012
}

Conflict of interests: none. 
do tecido tumoral revelou que, nas células C6, ainda encontramos uma vasta distribuição das nanopartículas superparamagnéticas de óxido de ferro. Conclusão: $A$ imagem por ressonância magnética apresenta-se com alto potencial para o monitoramento das células C6 marcadas eficientemente com nanopartículas superparamagnéticas de óxido de ferro na avaliação do crescimento tumoral.

Descritores: Glioma; Nanopartículas; Imagem por ressonância magnética; Modelos animais

\section{INTRODUCTION}

Brain tumors are defined as masses of abnormal cells in the brain that grow and multiply uncontrollably. In addition, brain tumors, as well as other types of cancer, can carry a poor prognosis according to the specific genetic mutations involved. In humans, glioma is a common tumor of the central nervous system (CNS) that can consist of astrocytes (astrocytomas), oligodendrocytes (oligodendrogliomas), ependymal cells (ependymomas), and a mixture of several different glial cell types (e.g., oligoastrocytomas) ${ }^{(1)}$. The most common human brain tumor, the astrocytoma, can be further classified according to its degree of malignant transformation into astrocytoma, anaplastic astrocytoma, or glioblastoma multiforme. The latter, a densely vascularized solid tumor characterized by the proliferation of blood vessels, endothelial cell hyperplasia, and endothelial cell cytology ${ }^{(2)}$, presents the highest degree of malignancy and can rapidly invade normal brain tissue to cause death within months. As brain tumors often carry poor prognoses, it is necessary to attempt to enhance the quality of life of brain tumor patients by pursuing the development of new therapies.

Advances in cellular therapies have led to the necessity of developing techniques to enable the monitoring of the transferred cells. The majority of the existing protocols require the use of histological analysis to evaluate the viability of transplanted cell grafts. Thus, the development of non-invasive techniques and the establishment of therapy protocols for use with real-time monitoring of the grafted cells are necessary to improve the clinical applications of cell therapies.

Nanotechnology, in conjunction with particle engineering, has enabled the targeting of specific cells to enhance clinical therapy ${ }^{(3,4)}$. Advances in molecular imaging have further enabled the use of non-invasive, real-time monitoring techniques for cell migration in vivo, and magnetic resonance imaging (MRI) plays an important role in both pre-clinical and clinical studies. For these types of studies, iron oxide-based nanoparticles with magnetic properties can be used for cell labeling ${ }^{(5-7)}$. MRI provides detailed information on anatomy and function, and this technique is commonly used for cell tracking assays in vivo in combination with contrast agents, such as superparamagnetic iron oxide nanoparticles (SPIONs). The growing interest related to the use of contrast agents to visualize the migration and growth of cells (e.g., stem cells or tumor cells) has made MRI a particularly interesting technique, as it can enable monitoring studies of cell migration and homing in vivo ${ }^{(8-11)}$.

Cells labeled with SPIONs for both in vivo and in vitro assays induce a strong contrast in $\mathrm{T}_{2}$ maps, which facilitates the monitoring of grafted cells. Using $\mathrm{T}_{2}$ - and $\mathrm{T}_{2}{ }^{*}$-weighted MRI, SPIONs are marked as blank regions or hypointense regions with associated artifacts ${ }^{(12)}$.

\section{OBJECTIVE}

The aim of the current study was to evaluate the migration of SPION-labeled C6 cells, which were used to induce glioblastoma in an animal model, over time using MRI.

\section{METHODS}

\section{Animals}

The present work was conducted according to the regulations of the Ethics in Animal Research Committee of the Albert Einstein Israelite Hospital (Comitê de Ética em Pesquisa Animal do Hospital Israelita Albert Einstein - HIAE). All of the procedures were conducted with an effort to use the minimum number of animals possible. Additionally, measures were taken to reduce animal suffering and stress throughout the duration of the experiments.

For the C6 model, 2-month-old male Wistar rats weighing between 250 and $300 \mathrm{~g}$ were used. The rats were divided into 2 groups: the first group $(n=3)$ received tumors induced via the injection of SPION-labeled C6 cells, and the second group $(n=3$, control group) received tumors induced via the injection of unlabeled C6 cells. The animals were housed at the vivarium of the Experimental Surgical Training Center at the Brain Institute (Centro de Experimentação e Treinamento em Cirurgia - CETEC, Instituto do Cérebro, HIAE) and were provided access to food and water ad libitum. The animals were housed in individual polypropylene cages containing autoclaved sawdust and stainless steel cover grids with divisions for balanced food and water. This vivarium received accreditation from the Association 
for the Assessment and Accreditation of Laboratory Animal Care International (AAALAC International). The animals were placed in an environment with a 12-hour day-night cycle (7-19 h) and a constant room temperature of $21 \pm 2^{\circ} \mathrm{C}$, according to international specifications.

For MRI acquisition, the animals were transported to the vivarium of the In Vivo Magnetic Resonance Imaging and Spectroscopy Center for the Study of Animal Models, which is part of the Physics Institute of São Carlos at the University of São Paulo in São Carlos (SP), Brazil (Centro de Imagens e Espectroscopia in vivo por Ressonância Magnética para Estudo de Modelos Animais - CIERMag, Instituto de Física da Universidade de São Paulo - USP, São Carlos SP). The animals remained at this location under the aforementioned conditions until the final stage of the experiments.

\section{C6 glioma cell culture}

Wistar rat glioma C6 cells were grown in Dulbecco's Eagle medium (Gibco ${ }^{\circledR}$, Gaithersburg, MD) supplemented with $20 \%$ fetal bovine serum (Invitrogen) at a temperature of $37^{\circ} \mathrm{C}\left(5 \% \mathrm{CO}_{2}\right)$ until the cells were $90 \%$ confluent. The culture medium was then removed, and the cells were detached using trypsin $(0.04 \%$ trypsin/EDTA). The cells were centrifuged at $800 \mathrm{rpm}$ for 5 minutes, resuspended in Dulbecco's medium at a final concentration of $10^{5}$ cells $/ 10 \mu \mathrm{L}$, and were kept refrigerated until implantation.

\section{SPION cell labeling}

For cell labeling, C6 cells grown to 70-80\% confluence were incubated overnight $\left(\sim 12 \mathrm{~h}\right.$ at $\left.37^{\circ} \mathrm{C}, 5 \% \mathrm{CO}_{2}\right)$ in $20 \mathrm{~mL}$ of culture medium with SPIONs (final concentration of $30 \mu \mathrm{g} \mathrm{Fe} / \mathrm{mL}$ ) and the transfection agent PLL (final concentration of $1.5 \mu \mathrm{g} / \mathrm{mL}$ ) (SigmaAldrich Chemie GmdH, Germany). After incubation, the supernatant was discarded, and the C6 cells were washed twice with phosphate-buffered saline (PBS) to remove extracellular SPIONs. SPION-labeled C6 cells were collected following treatment with trypsin and manually counted using a Neubauer chamber.

\section{In vitro analysis of SPION intracellular distribution in C6 cells}

The SPION-capturing capacity of the C6 cells was qualitatively evaluated according to the intracellular distribution and localization of the SPIONs using
Prussian Blue staining (Prussian Blue Kit from BioPAL) and light microscopy. Staining of the labeled C6 cells was performed for a duration of 2 minutes.

\section{Stereotaxic implantation of $\mathbf{C} \mathbf{6}$ cells}

For the SPION-labeled C6 cell implantation, animals were anesthetized with ketamine $(55 \mathrm{mg} / \mathrm{kg})$ and xylazine $(11 \mathrm{mg} / \mathrm{kg})$ and then administered a trichotomy of the upper region of the head. The animals were immobilized to a stereotaxic apparatus (Model 51700, Stoelting Co., USA) using in-ear and upper incisive teeth bars. After making a skin incision on the dorsal region of the cranium and removing the periosteum, the bone cap was trepanned with a dental drill. The cell implantation position was determined and marked on the bone according to Swanson's Stereotaxic Atlas ${ }^{(13)}$ at the following coordinates: anteroposterior $=2.0 \mathrm{~mm}$; laterolateral $=2.0 \mathrm{~m}$; and depth $=2.5 \mathrm{~mm}$. For tumor induction, $10^{5}$ of the labeled or non-labeled (control group) C6 cells in $10 \mu \mathrm{L}$ of culture medium were implanted into the right frontal cortex using a Hamilton syringe needle. The process was slowly performed for a period of 10 minutes. The needle was kept in position for an additional 2 minutes prior to its removal. To avoid drawing the solution back into the needle, the syringe was slowly raised until it was completely removed from the brain. The bone was reassembled with bone wax, and the skin was sutured with cotton thread.

\section{MRI tumor monitoring and SPION detection}

Prior to each image acquisition session, the animals were anesthetized with a mixture of ketamine $(95 \mathrm{mg} / \mathrm{kg})$ and xylazine $(12 \mathrm{mg} / \mathrm{kg})$. Magnetic resonance images were acquired using a $2 \mathrm{~T}$ field strength horizontal superconducting magnet (Model 65310HR, Oxford Instruments, Oxfordshire, UK) with a 150 -mm bore and 16-Gauss/cm gradient coils, which were operated in conjunction with a spectrometer (Biospin, Bruker ${ }^{\circledR}$, Germany). This system possesses a broadband receiver ( 2 to $400 \mathrm{MHz}$ ) as well as 2 transmission and 4 reception channels with parallel acquisition. Crossed saddle-type radiofrequency coils with an internal diameter of $56 \mathrm{~mm}$ were also used.

$\mathrm{T}_{2}$ and $\mathrm{T}_{2}{ }^{*}$ pulse sequences were collected for the brain morphological analysis. The rapid acquisition with relaxation enhancement (RARE) pulse sequence was selected for the $\mathrm{T}_{2}$-weighted image acquisition with the following parameters: $\mathrm{TR}=4.000 \mathrm{~ms}$; $\mathrm{TE}=67.1 \mathrm{~ms}$; RARE factor $=6$; means $=24$; and bandwidth $=12.5 \mathrm{KHz}$. These parameters resulted in a 50-minute acquisition 
time per animal. The FOV was $40 \times 40 \mathrm{~mm}^{2}$ with a $192 \times 192$ point array, which produced a spatial resolution of $208 \times 208 \mathrm{~mm}$. In addition, 260.5 -mm-thick slices were used without spacing between the slices. 3D fast low-angle shot (FLASH 3D) was the pulse sequence chosen for the $\mathrm{T}_{2}{ }^{*}$-weighted image acquisition with the following parameters: $\mathrm{TR}=48 \mathrm{~ms} ; \mathrm{TE}=6 \mathrm{~ms} ; 35^{\circ}$ flip angle; means $=6$; and bandwidth $=25 \mathrm{kHz}$. These parameters resulted in a 45-minute acquisition time per animal. The FOV was $40 \times 40 \times 30 \mathrm{~mm}^{3}$ with a $192 \times 192 \times 48$ point array, which produced a spatial resolution of $208 \times 208 \times 625 \mathrm{~mm}$.

\section{Tumor histological analysis: SPION identification}

Three hours after the image acquisition, the animals were subjected to histological analysis. For this purpose, the rats were anesthetized and transcardially perfused with a buffered saline solution followed by $4 \%$ paraformaldehyde (PFA). The brains were removed and stored in PFA for 24 hours prior to paraffin immersion. Four-micron-thick coronal slices were obtained with a microtome and were then stained using the standard basic fuchsine protocol. For SPION observation, the slices were counterstained with Prussian Blue.

\section{RESULTS}

Intracellular labeling of the aminosilane-coated SPION-incubated C6 cells in the presence of the transfection agent PLL was qualitatively evaluated using Prussian Blue staining and light microscopy. Figures $1 \mathrm{~A}$ and $1 \mathrm{~B}$ show unlabeled and SPION-labeled cells, respectively.

MRI monitoring of tumor growth according to the detection of SPION-labeled and unlabeled C6 glioma cells was performed 14 and 21 days after implantation. The set of images obtained using MRI following SPION-labeled or unlabeled C6 cell transplantation are shown in figures 2 and 3. The transverse relaxation time for the $\mathrm{T}_{2}$-weighted MRI of the tumors for both the unlabeled (control) and SPION-labeled cells at the 14- and 21-day time-points are shown in figure 2, whereas figure 3 shows the transverse relaxation time for the $\mathrm{T}_{2}{ }^{*}$-weighted MRI of the tumors for the same two time-points post-transplantation.

The $\mathrm{T}_{2}$-weighted images acquired 14 days following the implantation of unlabeled cells demonstrated the formation of a mass that had a maximum diameter of $6 \mathrm{~mm}$ and a high $\mathrm{T}_{2}$ signal intensity. In contrast, the $\mathrm{T}_{2}$-weighted images of the cells labeled with SPIONs

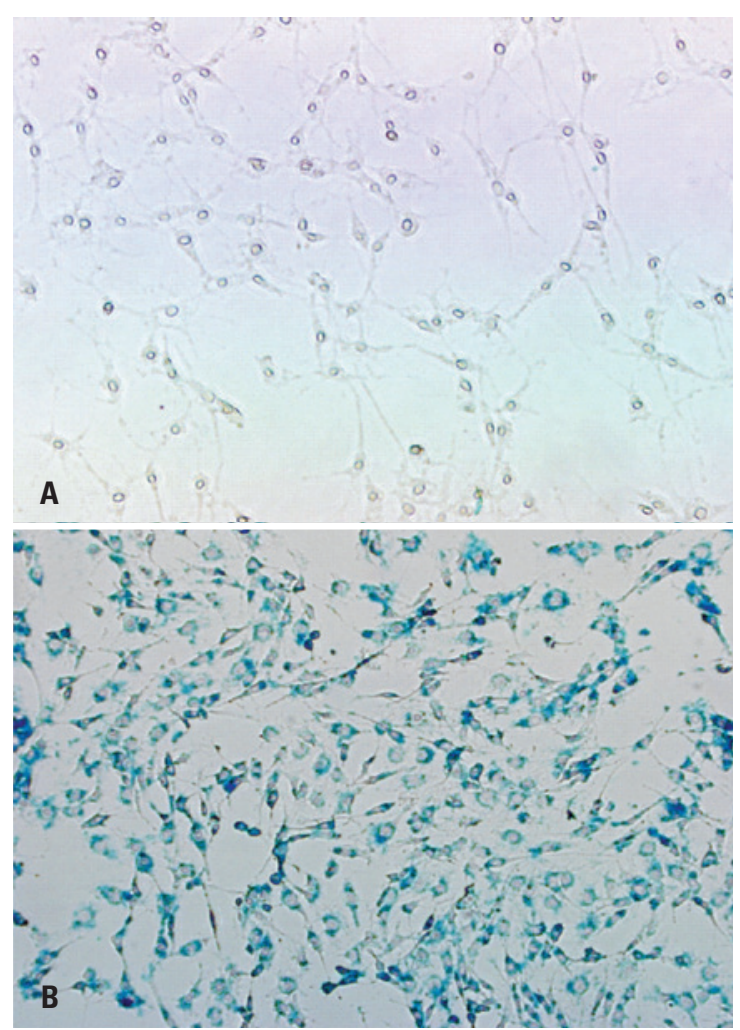

Figure 1. Light microscopy of unlabeled (A) and SPION-labeled, Prussian Bluecounterstained (B) C6 cells. Magnification $=400 \mathrm{X}$

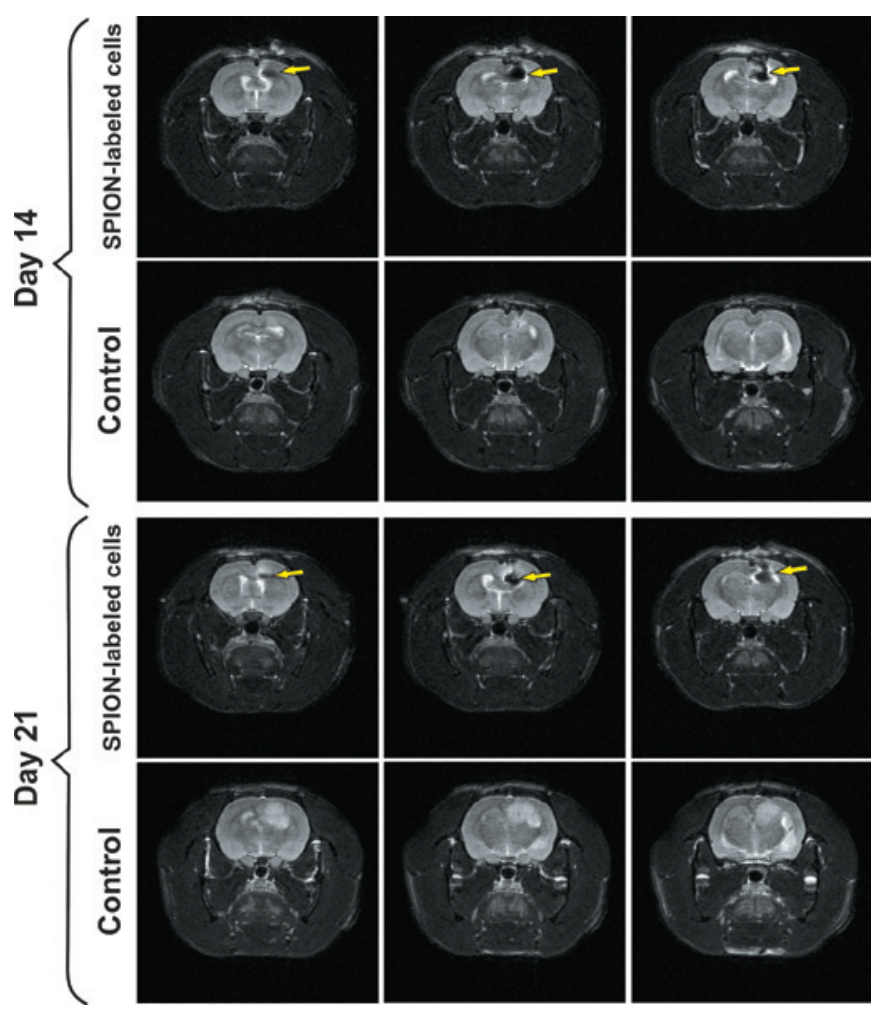

Figure 2. $\mathrm{T}_{2}$-weighted magnetic resonance imaging of tumor growth for the two groups studied the SPION-labeled C6 cell-induced tumor group and the unlabeled $\mathrm{C} 6$ cell-induced tumor group (control). Image acquisition was performed 14 and 21 days post-C6 cell implantation. The arrows indicate the SPION effect on the MRIs 


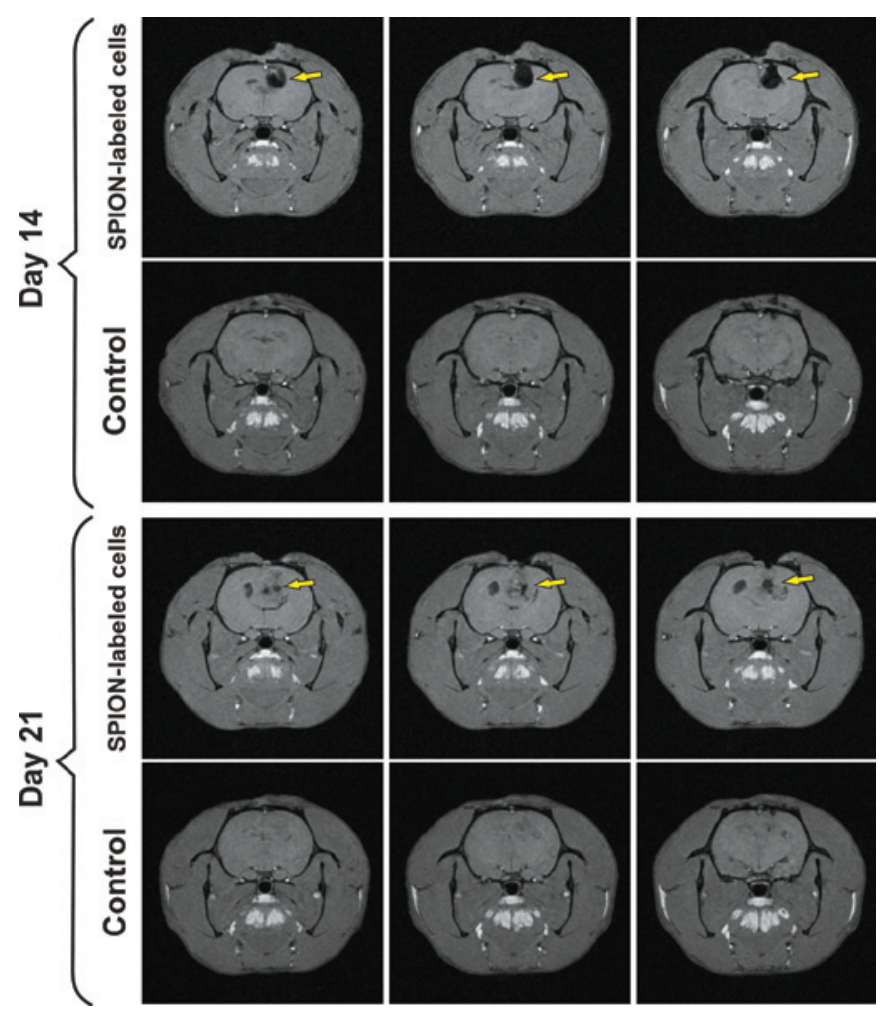

Figure 3. $\mathrm{T}_{2}{ }^{*}$-weighted magnetic resonance imaging of tumor growth for the two groups studied, the SPION-labeled C6 cell-induced tumor group and the unlabeled C6 cell-induced tumor group (control). Image acquisition was performed at 14 and 21 days post-C6 cell implantation. The arrows indicate the SPION effect on the MRIs

showed areas of high peripheral signal intensity, and the central and upper regions demonstrated a marked decrease in $\mathrm{T}_{2}{ }^{*}$ signal intensity (presumably due to the SPIONs). At day 21, the group of animals inoculated with the unlabeled cells demonstrated an increase in the high $\mathrm{T}_{2}$ signal intensity area as well as the loss of low T2 signal intensity areas, which indicated the growth of the tumor mass. Furthermore, the group of animals inoculated with the SPION-labeled cells also demonstrated an increase in tumor mass, which was mainly observed at the periphery of the high T2 signal intensity areas, but there was also a small central area showing low signal intensity. Similar findings were observed in the $\mathrm{T}_{2}{ }^{*}$-weighted images. However, the SPION-labeled cell group also demonstrated an area of markedly decreased $\mathrm{T}_{2}{ }^{*}$-weighted contralateral signal intensity in the ventricular ependymal projection, which potentially indicated the presence of SPIONs (and indirectly, tumor cells) in the contralateral hemisphere.

Following MRI acquisition, the tumor tissue was subjected to histological analysis for SPION detection (Figure 4) using the basic fuchsine protocol and Prussian Blue counterstaining. Notably, for the tissue adjacent to the tumor (Figure 4A), no SPIONs could be detected. However, SPIONs were detected intracellularly in the labeled C6 cell-induced tumor tissue (Figure 4B).
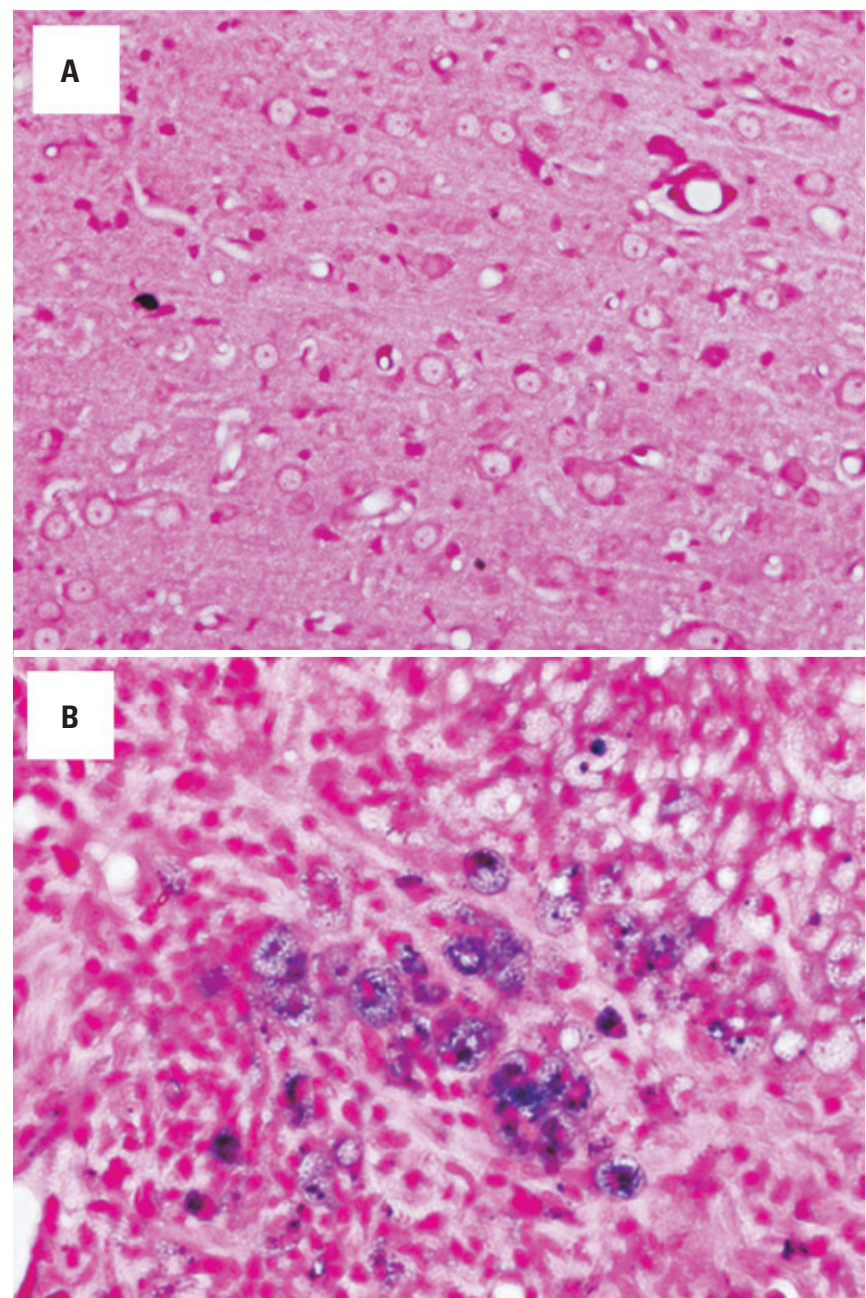

Figure 4. Histological analysis of tumor tissues (basic fuchsine protocol and counterstaining with Prussian Blue). (A) No SPIONs could be detected in the normal tissue adjacent to the tumor. (B) Tumor tissue containing intracellular SPIONs. Magnification $=400 \mathrm{X}$

\section{DISCUSSION}

The in vitro qualitative evaluation of aminosilanecoated and PLL-conjugated SPION-labeled C6 cells (final concentration of $30 \mu \mathrm{g} \mathrm{Fe} / \mathrm{mL}$ ) was performed using light microscopy following Prussian Blue staining. The nanoparticles were shown to be well distributed, and the SPION cell labeling was considered satisfactory. An adequate level of labeling efficiency is an important factor for MRI monitoring of grafted C6 cells and their proliferation.

$\mathrm{T}_{2}$ - and $\mathrm{T}_{2}{ }^{*}$-weighted images were collected for SPION-labeled cell mapping, which was characterized 
by the presence of hypointense regions. SPIONs, when used as contrast agents in MRI, establish a localized strong disrupting dipolar field, which leads to a marked decrease in $\mathrm{T}_{2}{ }^{*}$ as well as a less marked decrease in $\mathrm{T}_{1}$ images. These factors generate a negative contrast that enhances both the details and contours of the image $^{(14-17)}$.

Using MRI monitoring, we observed a reduction in the markedly low intensity of $\mathrm{T}_{2}$ and $\mathrm{T}_{2}{ }^{*}$ signals when comparing the images obtained at 14 and 21 days after cell implantation (Figures 2 and 3). This result was due to the presence of SPIONs within the lesion located in the frontal left lobe on parasagittal topography. The location of the dark areas corresponded to the presence of SPIONlabeled glioma C6 cells. A qualitative evaluation of the images presented in figures 2 and 3 demonstrated an accumulation of SPIONs within the C6 glioma cells, which indicated that SPION retention had occurred. At 21 days after $\mathrm{C} 6$ cell implantation (Figures 2 and 3), radical diffusion was observed from the location where the cells were first grafted, along with a concomitant decrease in hypointensity. This result was likely attributed to iron dilution due to cell proliferation $^{(18)}$ and potential degradation of the aminosilane coating of a fraction of the SPIONs, which could have modified the superparamagnetic properties of the particles due to changes in crystalline structure. Another potential explanation for the observed signal intensity decrease was the presence of a hemoglobin residue, which may have been present in hemorrhage areas. Although it was not possible to distinguish between these two hypotheses solely according to the MRIs, these features were not present in the control group of animals, which suggests a low likelihood of hemorrhage in either group.

Moreover, the histological analysis according to Prussian Blue staining revealed a vast distribution of SPIONs in the tumor tissue. The nanoparticles were found in both the extracellular and intracellular medium, but SPIONs were not detected in the tissues adjacent to the tumor (Figure 2).

\section{CONCLUSION}

In the present study, C6 glioma cells were effectively labeled with aminosilane-coated, PLL-conjugated SPIONs.

Non-invasive MRI analysis was shown to be a valuable tool when combined with effective SPIONlabeling techniques to monitor the migration trajectory and glioblastoma tumor growth of transferred C6 cells for determined periods of time. This monitoring was performed by obtaining $\mathrm{T}_{2}$ - and $\mathrm{T}_{2}{ }^{*}$-weighted MRIs.

\section{ACKNOWLEDGEMENTS}

The present work was supported by the Instituto Israelita de Ensino e Pesquisa - IIEPAE, Conselho Nacional de Desenvolvimento Científico e Tecnológico - CNPq, Financiadora de Estudos e Projetos - FINEP, Coordenação de Aperfeiçoamento de Pessoal de Nível Superior - CAPES, and Fundação de Amparo à Pesquisa do Estado de São Paulo - FAPESP.

\section{REFERENCES}

1. Dai C, Holland EC. Glioma models. Biochim Biophys Acta. 2001;1551(1):M19-27.

2. Brem S, Cotran R, Folkman J. Tumor angiogenesis: a quantitative method for histological grading. J Natl Cancer Inst. 1972;48(2):347-56.

3. Koo YE, Reddy GR, Bhojani M, Schneider R, Philbert MA, Rehemtulla A, et al. Brain cancer diagnosis and therapy with nanoplatforms. Adv Drug Deliv Rev. 2006;58(14):1556-77.

4. Reddy GR, Bhojani MS, McConville P, Moody J, Moffat BA, Hall DE, et al. Vascular targeted nanoparticles for imaging and treatment of brain tumors. Clin Cancer Res. 2006;12(22):6677-86.

5. Billotey C, Aspord C, Beuf O, Piaggio E, Gazeau F, Janier MF, et al. T-cell homing to the pancreas in autoimmune mouse models of diabetes: in vivo MR imaging. Radiology. 2005;236(2):579-87.

6. Lee JS, Kang HJ, Gong G, Jung HD, Lim KH, Kim ST, et al. MR imaging of in vivo recruitment of iron oxide-labeled macrophages in experimentally induced soft-tissue infection in mice. Radiology. 2006;241(1):142-8.

7. Bourrinet $P$, Bengele $H H$, Bonnemain B, Dencausse A, Idee JM, Jacobs PM, et al. Preclinical safety and pharmacokinetic profile of ferumoxtran-10, an ultrasmall superparamagnetic iron oxide magnetic resonance contrast agent. Invest Radiol. 2006;41(3):313-24.

8. Ke YQ, Hu CC, Jiang XD, Yang ZJ, Zhang HW, Ji HM, et al. In vivo magnetic resonance tracking of Feridex-labeled bone marrow-derived neural stem cells after autologous transplantation in rhesus monkey. J Neurosci Methods. 2009;179(1):45-50.

9. Gultepe E, Reynoso FJ, Jhaveri A, Kulkarni P, Nagesha D, Ferris C, et al. Monitoring of magnetic targeting to tumor vasculature through MRI and biodistribution. Nanomedicine (Lond). 2010;5(8):1173-82.

10. Caruso G, Caffo M, Alafaci C, Raudino G, Cafarella D, Lucerna S, et al. Could nanoparticle systems have a role in the treatment of cerebral gliomas? Nanomedicine. 2011;7(6):744-52

11. Breton E, Goetz Ch, Kintz J, Accart N, Aubertin G, Grellier B, et al. In vivo preclinical low-field MRI monitoring of tumor growth following a suicide gene therapy in an orthotopic mice model of human glioblastoma. C R Biol. 2010;333(3):220-5

12. Chertok B, Moffat BA, David AE, Yu F, Bergemann C, Ross BD, et al. Iron oxide nanoparticles as a drug delivery vehicle for MRI monitored magnetic targeting of brain tumors. Biomaterials. 2008;29(4):487-96.

13. Swanson LW. Brain maps: structure of the rat brain. Philadelphia: Elsevier; 1992.

14. Huang J, Zhong $X$, Wang L, Yang L, Mao H. Improving the magnetic resonance imaging constrast and detection methods with engineered magnetic nanoparticles. Theranostics. 2012; 2(1):86-102. 
15. Liu W, Frank JA. Detection and quantification of magnetically labeled cells by cellular MRI. Eur J Radiol. 2009;70(2):258-64.

16. Wang J, Xie J, Zhou X, Cheng Z, Gu N, Teng G, et al. Ferritin enhances SPIO tracking of C6 rat glioma cells by MRI. Mol Imaging Biol. 2011;13(1):87-93.

17. Liu W, Dahnke H, Jordan EK, Schaeffter T, Frank JA. In vivo MRI using positive- contrast techniques in detection of cells labeled with superparamagnetic iron oxide nanoparticles. NMR Biomed. 2008;21 (3):242-50.

18. Zhang F, Xie J, Liu G, He Y, Lu G, Chen X. In vivo MRI tracking of cell invasion and migration in a rat glioma model. Mol Imaging Biol. 2011;13(4): 695-701. 